\title{
PENGEMBANGAN FORMULIR DIGITAL RAPID CONVENIENCE ASSESSMENT IMUNISASI DASAR DAN LANJUTAN BERBASIS EPICOLLECT5 DATA COLLECTION DI PROVINSI BALI
}

\author{
Putu Dwiki Damadita, I Ketut Tangking Widarsa* \\ Program Studi Sarjana Kesehatan Masyarakat Fakultas Kedokteran Universitas Udayana \\ *Email: twidarsa@yahoo.com
}

\begin{abstract}
ABSTRAK
Rapid Convenience Assessment (RCA) imunisasi dasar dan lanjutan merupakan survei cakupan imunisasi yang dilaksanakan sebagai bentuk penilaian terhadap pelaksanaan imunisasi dasar dan lanjutan. Proses pengumpulan data pada kegiatan RCA imunisasi dasar dan lanjutan mengalami beberapa permasalahan, yaitu adanya pengulangan pencatatan data dari kuesioner ke dalam komputer, adanya missing data dan data yang bermasalah. Aplikasi Epicollect5 Data Collection dapat dijadikan sebagai solusi untuk mengatasi permasalahan tersebut. Tujuan penelitian ini adalah untuk mengembangkan formulir digital RCA imunisasi dasar dan lanjutan berbasis Epicollect5 Data Collection. Penelitian ini menggunakan pendekatan participatory action research dan model pengembangan System Development Life Cycle (SDLC), dengan melibatkan 11 orang pegawai dan petugas imunisasi di Dinas Kesehatan Provinsi Bali, Dinas Kesehatan Kabupaten Tabanan, Badung, Gianyar dan Kota Denpasar sebagai subyek penelitian. Penelitian dilakukan dari bulan Maret hingga Mei 2020. Pengembangan formulir digital dilakukan melalui tiga tahapan, yaitu identifikasi kebutuhan informasi RCA, pengembangan prototipe formuir digital, dan uji coba. Formulir digital dibuat dalam aplikasi Epicollect5 Data Collection dan terdiri dari 5 bagian utama, yaitu form identitas formulir, lokasi RCA imunisasi, identitas responden, imunisasi dasar, dan imunisasi lanjutan. Output data yang dapat dihasilkan oleh formulir digital dalam website Epicollect yaitu berupa tabel, pemetaan lokasi, dan analisis sederhana. Uji coba dilakukan pada 11 pegawai dan petugas imunisasi yang menjadi subyek penelitian. Hasil uji coba menunjukan bahwa petugas imunisai mendukung penggunaan formulir digital dilihat dari aspek ekspektasi kinerja, ekspektasi usaha dan minat memanfaatkan. Diharapkan formulir digital yang dikembangkan dapat digunakan dalam kegiatan RCA imunisasi yang dilaksanakan Dinas Kesehatan Provinsi Bali di masa mendatang.
\end{abstract}

Kata kunci: Pengembangan formulir digital, RCA imunisasi dasar dan lanjutan, Epicollect5 Data Collection

\begin{abstract}
Rapid Convenience Assessment (RCA) of immunization is an immunization coverage survey that is carried out as an assessment of the immunization program's implementation. The process of data recording in RCA of immunization program had several problems, such as repeated data entry from the questionnaire into the computer, missing data, and problematic data. Epicollect5 Data Collection application can be used as a solution to solve these problems. This study aims to develop a digital form for RCA of immunization based on using Epicollect5 Data Collection. This study used a participatory action research approach with the System Development Life Cycle (SDLC) development model, involving 11 immunization officers as the research's subjects from the Health Office of Bali Province, Health Office of Denpasar City, Tabanan, Badung, and Gianyar Regency. The study was conducted from March to May 2020. The development of digital forms was carried out through three stages, namely identification of RCA information needs, development of digital form prototypes, and field tests. The digital form was created in the Epicollect5 Data Collection application and consists of 5 main parts, namely the form identity, location of the RCA immunization, respondent identity, basic immunization, and advanced immunization. The output data that can be generated from the epicollect website are tables of data, mapping, and simple analysis. The results of the field test conducted by 11 immunization officers indicate that the immunization officers support the use of digital forms in terms of performance expectancy, effort expectancy, and behavioral intention. It is hoped that the digital form can be used in the RCA immunization program carried out by the Health Office of Bali Province in the future.
\end{abstract}

Keywords: Digital form development, RCA of immunization, Epicollect5 Data Collection 


\section{PENDAHULUAN}

Rapid Convenience Assessment (RCA) imunisasi dasar dan lanjutan merupakan kegiatan survei cepat yang dilaksanakan oleh Dinas Kesehatan Provinsi Bali dengan tujuan untuk menilai cakupan imunisasi dasar dan lanjutan, menggambarkan faktor risiko atau hal yang menyebabkan sasaran tidak melaksanakan munisasi, serta menggambarkan sumber informasi yang diakses oleh sasaran untuk mengetahui informasi terkait imunisasi. Kegiatan RCA imunisasi dilaksanakan satu kali dalam setahun di setiap kabupaten/kota dengan menyasar daerah dengan cakupan imunisasi yang rendah dan mobilitas penduduk yang tinggi. Responden dalam kegiatan RCA imunisasi adalah orang tua yang memiliki bayi dengan usia minimal 10 bulan dan maksimal 3 tahun (Dinas Kesehatan Provinsi Bali B, 2019).

Berdasarkan studi pendahuluan, terdapat beberapa permasalahan yang dialami pada pelaksanaan RCA imunisasi dasar dan lanjutan. Akibat masih menggunakan kuesioner berbasis kertas, maka proses pencatatan data dilakukan sebanyak dua kali, yaitu pada memasukan data hasil wawancara dan observasi ke dalam kuesioner, dan ketika memasukan data secara manual dari kuesioner ke dalam dokumen microsoft excel. Hal tersebut menyebabkan proses pengumpulan data berjalan kurang efektif dan efisien. serta menghambat analisis data sehingga memerlukan waktu cukup lama untuk memperolah hasil analisis. Selain permasalahan tersebut, pada data yang dihasilkan dari kegiatan RCA imunisasi masih ditemukan adanya missing data dan data yang bermasalah karena kesalahan petugas survei dalam mengisi kuesioner.

Seiring dengan perkembangan zaman, penggunaan teknologi informasi berbasis digital dalam bidang kesehatan semakin banyak ditemukan. Sistem kerja secara manual dapat diganti dengan menggunakan sistem terkomputerisasi yang mampu mempermudah pekerjaan (Rasyid, Notobroto, \& Hargono, 2016). Salah satu upaya yang dapat dilakukan guna mengatasi permasalahan dalam pelaksanaan RCA imunisasi dasar dan lanjutan adalah menggunakan sistem berbasis digital dalam kegiatan pengumpulan data sebagai pengganti sistem manual. Dalam pelaksanaan kegiatan survei, sistem digitalisasi mampu meningkatkan kapasitas dan kecepatan pengumpulan data, serta memperkecil biaya yang diperlukan dalam pelaksanaan survei (Belasario et al., 2015). Salah satu perangkat lunak atau aplikasi yang menyediakan fitur formulir kuesioner digital yang dapat digunakan dalam kegiatan RCA imunisasi dasar dan lanjutan yaitu Epicollect5 Data Collection.

\section{Epicollect5 Data Collection}

merupakan aplikasi berbasis website yang memungkinkan pengguna melakukan pengumpulan data (termasuk data koordinat lokasi dan media gambar) dengan menggunakan ponsel pintar (smartphone), serta dapat melakukan penyuntingan data melalui website (Aanensen et al, 2009). Sebuah penelitian menunjukan bahwa penggunaan epicollect dalam kegiatan pengumpulan data pemantauan spesies kutu invasif dapat diterima dengan baik oleh stakeholders 
terkait karena mudah digunakan dan tidak memerlukan pelatihan khusus untuk menggunakan epicollect dalam proses pengumpulan data (Madder et al., 2012). Dibandingkan dengan aplikasi penyedia formulir digital yang lainnya, Epicollect5 Data Collection memiliki beberapa kalebihan, yaitu mampu digunakan pada ponsel pintar dengan sistem operasi android dan iOS, serta mampu mengumpulkan berbagai jenis data termasuk data koordinat lokasi menggunakan GPS dan data multimedia (gambar, audio, dan video). Berdasarkan data dari Badan Pusat Statistik Provinsi Bali, persentase penduduk Bali pada tahun 2019 yang menggunakan telepon seluler adalah $82,96 \%$, dan persentase penduduk yang mengakses internet adalah 54,08\% (BPS Provinsi Bali, 2020). Kondisi tersebut dapat mendukung penggunaan formulir digital RCA imunisasi karena sebagian besar masyarakat telah terbiasa menggunakan ponsel dan akses internet.

Berdasarkan pada uraian tersebut, maka penulis tertarik untuk mengembangkan formulir digital Rapid Convenience Assessment (RCA) imunisasi dasar dan lanjutan berbasis aplikasi Epicollect5 Data Collection di Provinsi Bali. Tujuan dari penelitian ini yaitu untuk mengembangkan rancangan formulir digital RCA imunisasi dasar dan lanjutan berbasis Epicollect5 Data Collection, serta menganalisis persepsi pengguna terhadap penggunaan formulir digital RCA imunisasi dasar dan lanjutan berbasis Epicollect5 Data Collection yang meliputi aspek ekspektasi kegunaan, ekspektasi usaha, dan minat memanfaatkan.

\section{METODE PENELITIAN}

Penelitian ini menggunakan metode pendekatan participatory action research dengan menggunakan model pengembangan System Development Life Cycle (SDLC). Penelitian dilakukan mulai dari bulan Maret hingga Mei 2020.

Pemilihan subyek penelitin dilakukan dengan cara purpossive, yaitu berjumlah 11 orang terdiri dari petugas imunisasi dan pegawai seksi surveilans dan imunisasi Dinas Kesehatan Provinsi Bali, serta petugas imunisasi di Dinas Kesehatan Kabupaten Tabanan, Kabupaten Badung, Kabupaten Gianyar, dan Kota Denpasar. Subyek penelitian tersebut merupakan pihak yang akan menjadi pengguna dari formulir digital yang dikembangkan.

$$
\text { Langkah-langkah }
$$

kegiatan pengembangan formulir digital yaitu identifikasi kebutuhan pada pengguna, mengembangkan rancangan formulir digital, uji coba, dan evaluasi. Identifikasi kebutuhan pengguna adalah tahap awal pengembangan dengan tujuan untuk mengetahui informasi yang dibutuhkan pengguna untuk dimuat pada formulir digital RCA imunisasi. Pengumpulan data pada tahap identifikasi kebutuhan dilakukan melalui wawancara kepada petugas imunisasi Dinas Kesehatan Provinsi Bali dengan panduan berupa checklist yang memuat pertanyaan mengenai apakah informasi yang dikumpulkan pada kegiatan RCA tahun sebelumnya masih perlu dikumpulkan melalui formulir digital, dan informasi tambahan apa saja yang perlu ditambahkan pada formulir digital. Selanjutnya, tahap perancangan prototipe formulir digital dilakukan dengan mengacu pada hasil 
identifikasi kebutuhan pengguna. Proses perancangan formulir digital dilakukan oleh peneliti pada website https://five.epicollect.net/melalui tiga tahap utama, yaitu create, design, dan collect. Formulir digital yang telah selesai dirancang akan dilakukan uji coba kepada subyek penelitian. Tujuan uji coba yaitu untuk menguji fungsi pada formulir digital dan memastikan formulir yang dikembangkan dapat digunakan oleh pengguna. Uji coba dilakukan oleh subyek penelitian dengan mencoba memasukan data ke dalam formulir digital. Setelah uji coba, dilakukan evaluasi untuk mengetahui persepsi subyek penelitian terkait penerimaan formulir digital serta meminta masukan/saran mengenai formulir digital yang dicoba. Persepsi dinilai dengan menggunakan aspek penilaian menurut model Unified Theory of Acceptance and Use of Technology (UTAUT), yaitu ekspektasi kinerja, ekspektasi usaha, dan minat memanfaatkan formulir digital.

\section{HASIL}

\section{Rancangan Formulir Digital RCA Imunisasi Dasar Dan Lanjutan}

Formulir digital RCA imunisasi dikembangkan dan dirancang pada website dengan alamat https://five.epicollect.net. Formulir digital ini dirancang untuk digunakan pada ponsel pintar melalui aplikasi Epicollect5 Data Collection. Pertanyaan-pertanyaan yang dimuat dalam formulir digital RCA imunisasi mengacu pada hasil identifikasi kebutuhan pengguna.
Setiap item pertanyaan pada formulir digital ditambahkan dengan fitur required, yaitu fitur yang mewajibkan pertanyaan untuk dijawab, dan apabila tidak dijawab maka petugas survei tidak akan dapat melanjutkan ke pertanyaan berikutnya. Penggunaan fitur required sangat membantu untuk mencegah terjadinya missing data atau pertanyaan yang tidak dijawab. Selain itu, beberapa pertanyaan pada formulir digital didesain dengan penambahan fitur jumps yang memungkinkan formulir digital untuk melompati pertanyaan secara otomatis berdasarkan jawaban tertentu dari responden, sehingga pertanyaan yang muncul merupakan pertanyaan yang memang perlu untuk dijawab oleh responden. Penambahan fitur jumps dapat mencegah terjadinya kesalahan petugas survei dalam melakukan pengisian formulir, sehingga dapat menghasilkan data yang lebih akurat. Pertanyaanpertanyaan pada formulir digital dapat dikelompokan menjadi 5 form bagian, yaitu:

a. Form Identitas Formulir.

Seluruh formulir yang telah terisi data akan disimpan dalam bentuk daftar. Untuk mempermudah dalam mengidentifikasi formulir yang sudah tersimpan, maka setiap formulir diberi judul dan identitas berdasarkan jawaban dari 3 pertanyaan pada Gambar 1. Untuk pertanyaan nomor urut responden diisi berdasarkan urutan dari responden yang diwawancara oleh masing-masing petugas survei. 


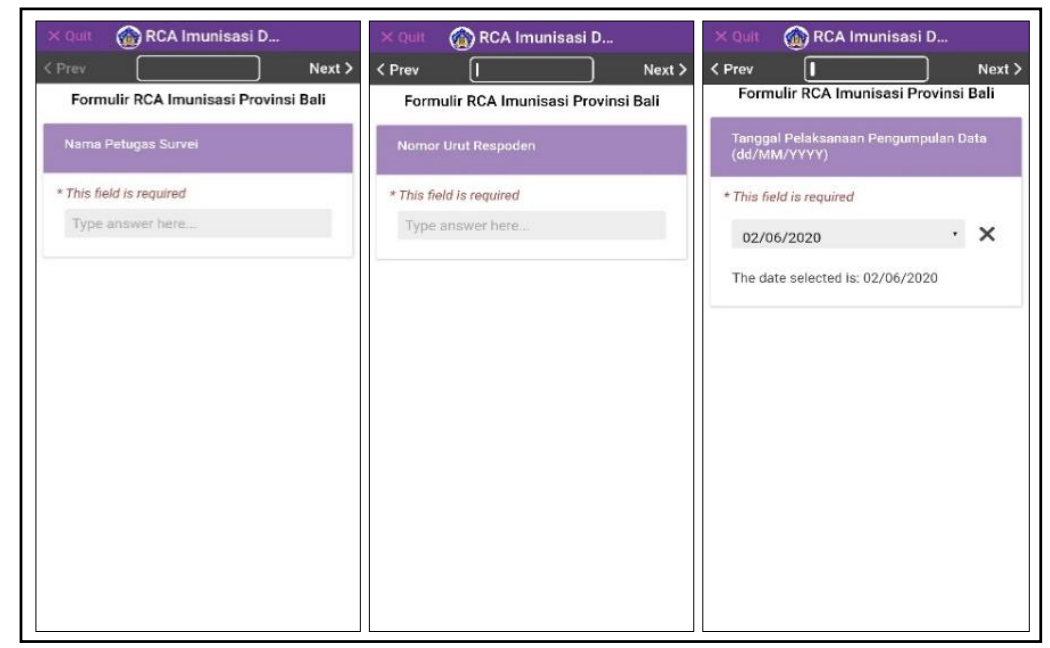

Gambar 1. Tampilan Antar Muka Pertanyaan Bagian Form Identitas Formulir.

b. Form lokasi pelaksanaan RCA imunisasi

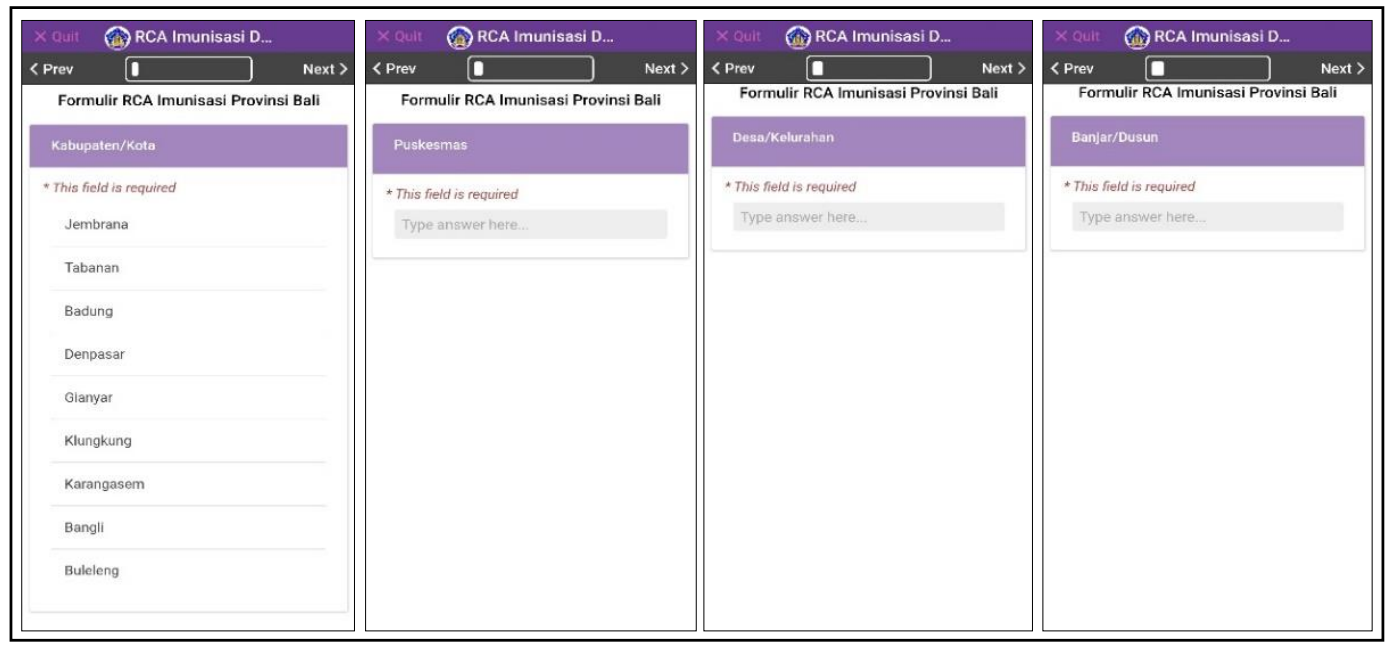

Gambar 2. Tampilan Antar Muka Pertanyaan Bagian Form Lokasi Pelaksanaan RCA Imunisasi.

c. Form identitas responden

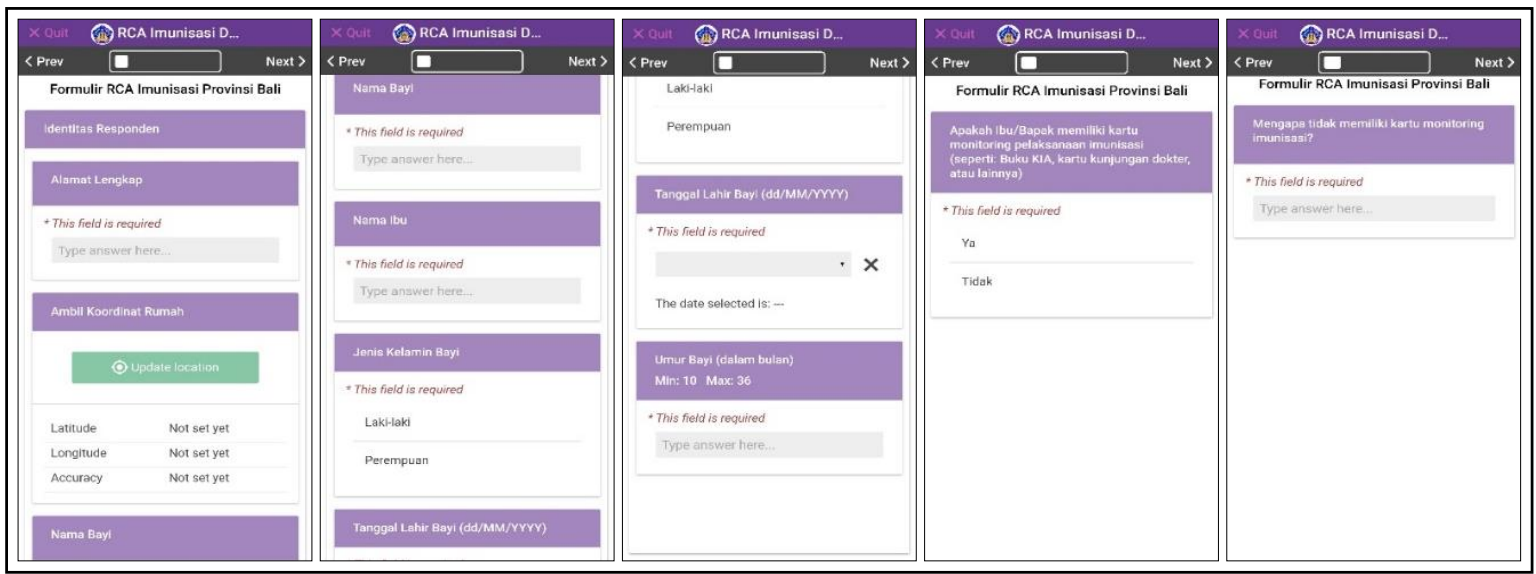

Gambar 3. Tampilan Antar Muka Pertanyaan Bagian Form Identitas Responden. 
Bagian identitas responden terdiri dari 9 pertanyaan. Untuk bagian mengambil koordinat rumah, diwajibkan untuk mengambil koordinat dengan angka akurasi yang terkecil. Untuk pertanyaan "Nama Ibu" diharapkan memasukan nama lengkap, dan diperbolehkan memasukan nama ayah apabila nama ibu tidak diketahui. Umur bayi dihitung dalam satuan bulan, terhitung dari tanggal lahir sampai tanggal pelaksanaan wawancara dengan responden. Tanggal lahir bayi dapat dilihat pada buku KIA atau kartu monitoring imunisasi. d. Form imunisasi dasar.

Terdapat 12 jenis imunisasi dasar, yaitu imunisasi HB0, BCG, Polio 1, DPTHB-Hib 1, Polio 2, DPT-HB-HIB 2, Polio 3, DPT-HB-Hib 3, Polio 4, IPV, Campak/Measles Rubella (MR), dan imunisasi Japanese encephalitis (JE). Pertanyaan untuk setiap jenis imunisasi dasar adalah sama, yaitu seperti ditampilkan pada gambar 4. Apabila semua pertanyaan untuk satu jenis imunisasi dasar telah ditanyakan, maka akan lanjut menuju pertanyaan untuk jenis imunisasi dasar berikutnya.

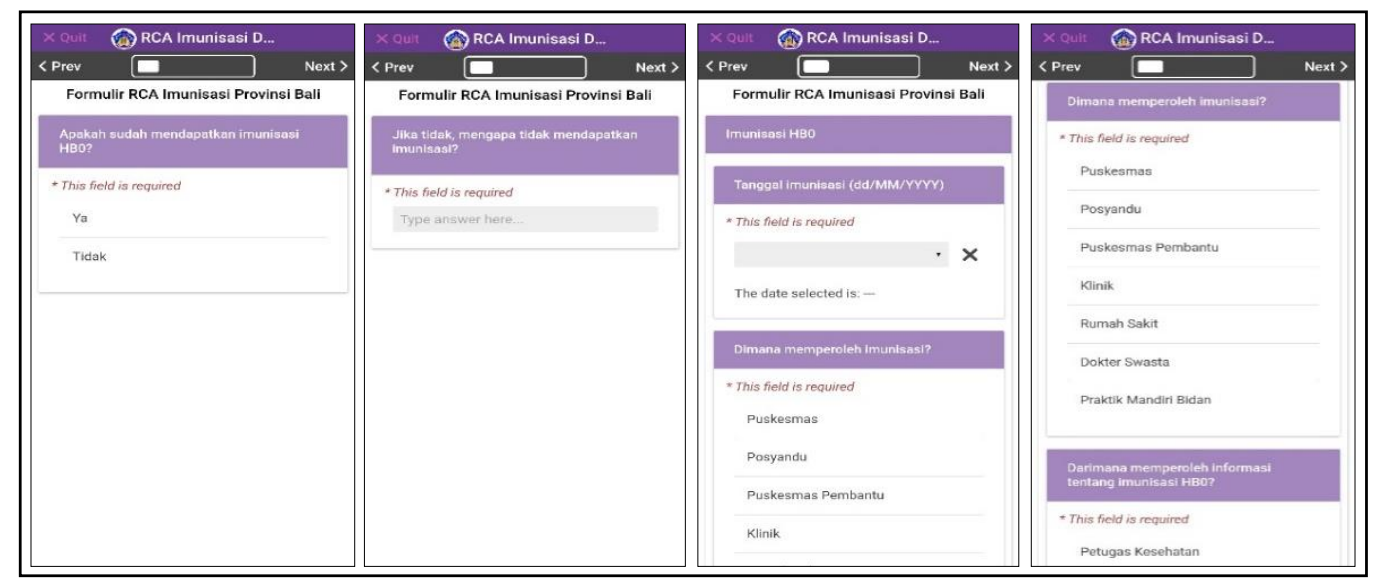

Gambar 4. Tampilan Antar Muka Pertanyaan Bagian Form Imunisasi Dasar.

Status bayi memperoleh imunisasi dasar serta tanggal memperoleh imunisasi dapat dilihat pada buku KIA/kartu monitoring imunisasi, atau ditanyakan kepada orang tua bayi.

e. Form Imunisasi Lanjutan.

Imunisasi lanjutan terdiri dari dua jenis imunisasi, yaitu DPT-HB-Hib lanjutan dan Campak/MR lanjutan yang diberikan kepada anak setelah berusia 18 bulan. Sebelum pertanyaan imunisasi lanjutan, responden harus menjawab pertanyaan status usia anak apakah sudah berusia 18 bulan. Apabila anak sudah berusia 18 bulan, maka pertanyaan imunisasi lanjutan akan ditampilkan pada formulir digital, dan apabila belum berusia 18 bulan, maka proses pengumpulan data akan selesai dan akan langsung diarahkan menuju akhir dari formulir digital. Pertanyaan untuk setiap jenis imunisasi lanjutan adalah sama, yaitu seperti ditampilkan gambar 5 . Apabila semua pertanyaan untuk satu jenis imunisasi lanjutan telah ditanyakan, maka akan lanjut menuju pertanyaan untuk jenis imunisasi lanjutan berikutnya. 


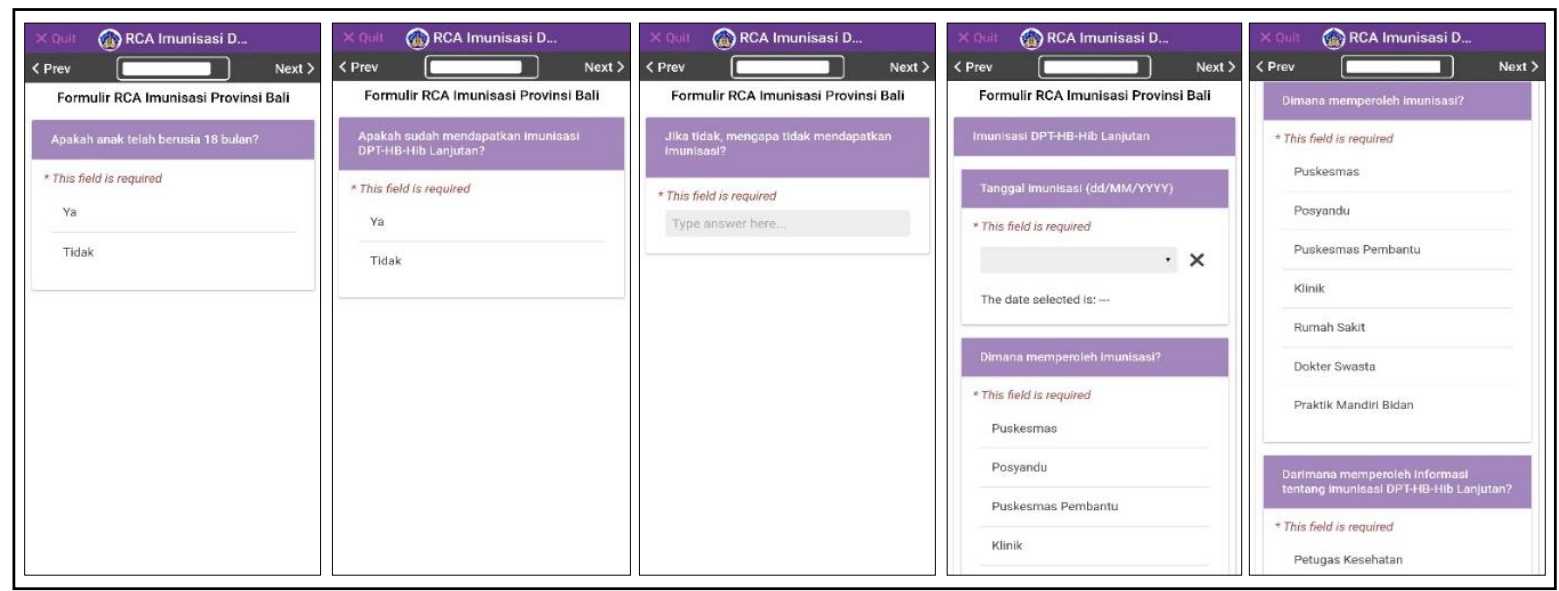

\section{Gambar 5. Tampilan Antar Muka Pertanyaan Bagian Form Imunisasi Lanjutan}

Pada form imunisasi dasar dan imunisasi lanjutan, pertanyaan tanggal imunisasi, lokasi memperoleh imunisasi, dan sumber informasi ditampilkan dalam satu halaman yang sama pada formulir digital untuk mempermudah proses pengisian data. Alur pengisian formulir digital dapat dilihat pada gambar berikut.

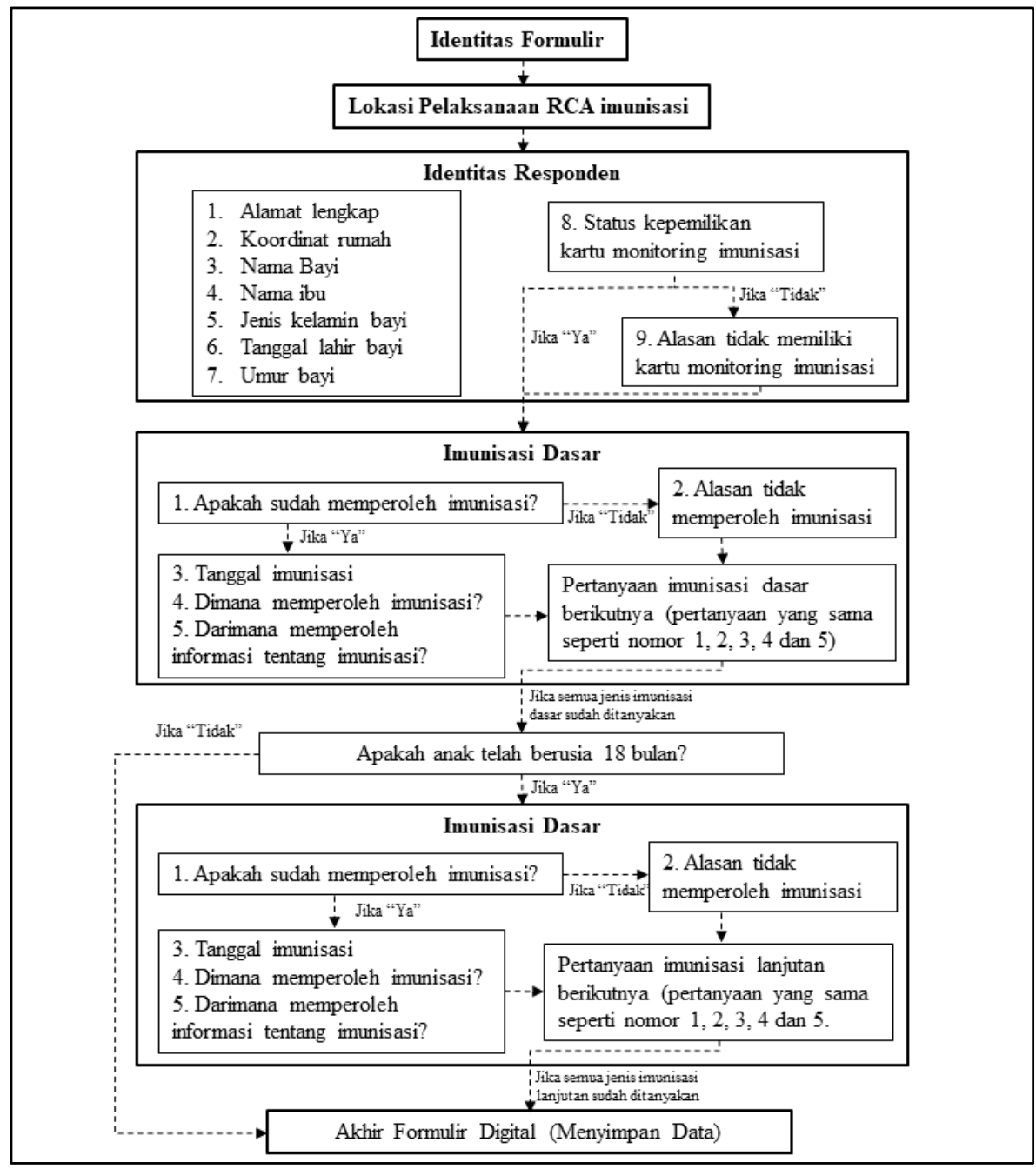

Gambar 6. Alur Pengisian Formulir Digital RCA Imunisasi. 
Data yang telah dikumpulkan dan disimpan dalam formulir digital selanjutnya akan dikirim ke server Epicollect. Data yang telah masuk ke dalam server Epicollect ditampilkan dalam bentuk tabel seperti yang ditampilkan pada gambar 7.A. Seluruh data yang telah masuk ke server Epicollect dapat diunduh dalam format .csv yang selanjutnya dapat dikonversi menjadi dokumen microsoft excel dengan format .xls atau .xlsx. Dalam proses analisis data, dokumen dengan format microsoft excel dapat dibuka dalam perangkat lunak pengolah data, sehingga dapat dilakukan analisis terhadap data di dalam dokumen excel tersebut. Tampilan data yang telah diunduh menjadi dokumen microsoft excel dapat dilihat pada gambar 7.B.

Selain menampilkan data dalam bentuk tabel, website Epicollect juga dapat menampilkan peta sederhana dalam bentuk dot maps atau peta titik yang menggambarkan lokasi rumah responden yang dikunjungi oleh petugas survei. Luaran berupa peta digunakan untuk melakukan validasi dan memastikan petugas survei melakukan pengumpulan data dengan mengadakan kunjungan rumah dan wawancara dengan responden. Pada peta yang ditampilkan oleh website Epicollect, terdapat fitur analisis sederhana yang mampu menampilkan distribusi frekuensi dari pertanyaan atau variabel yang diinginkan. Distribusi dari pertanyaan atau variabel ditampilkan dalam bentuk diagram lingkaran seperti pada gambar 7.D. Berbeda dengan output data berupa tabel yang dapat diunduh, hasil analisis sederhana yang dilakukan pada website epicollect tidak dapat diunduh, melainkan hanya dapat ditampilkan pada website.

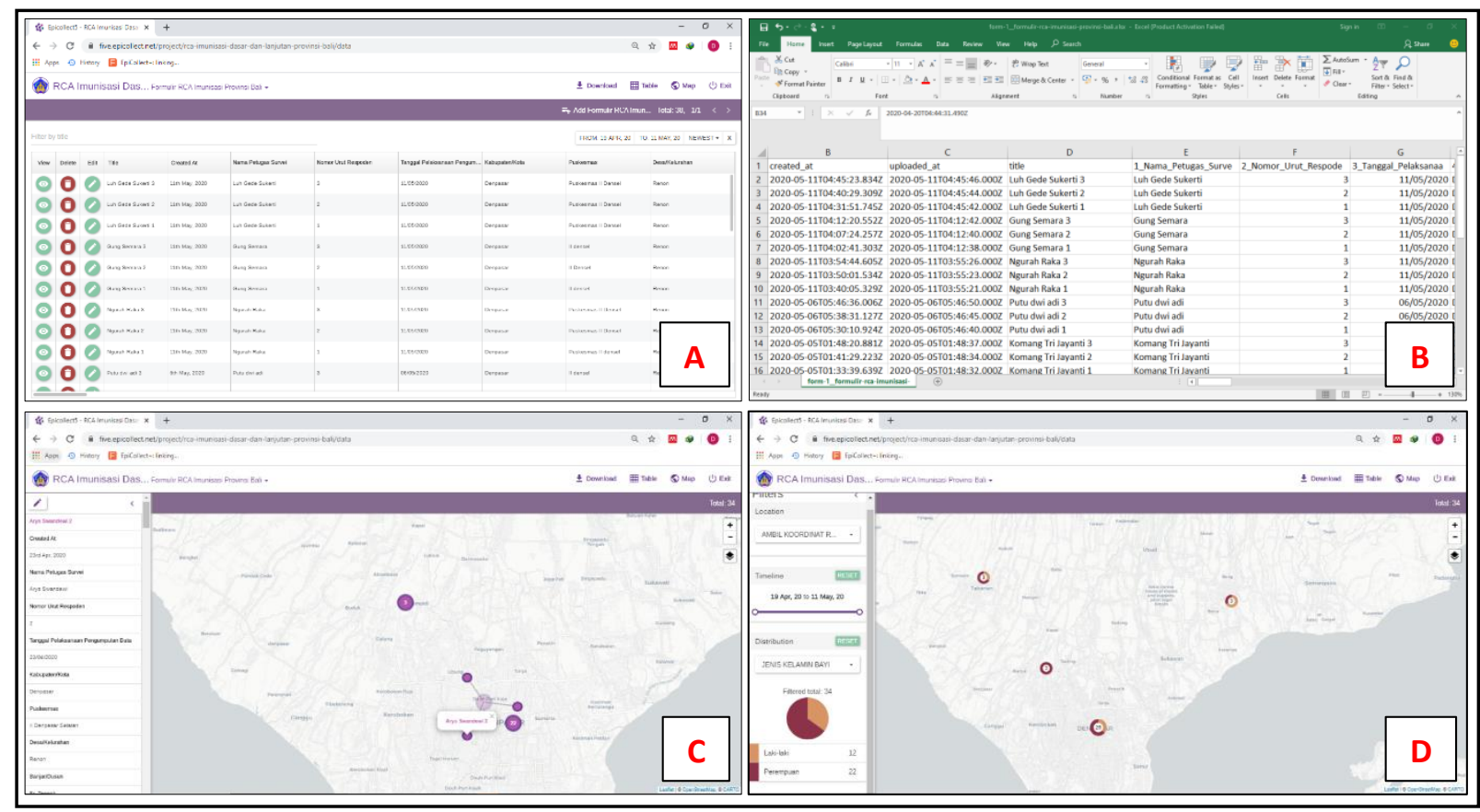

Gambar 7. Output Dari Formulir Digital RCA Imunisasi: a) Tampilan data pads website epicollect; b) Tampilan data dokumen excel yang diunduh dari website epicollect; c) Tampilan peta pada website epicollect; d) Tampilan hasil distribusi frekuensi variabel pada website epicollect. 


\section{Uji Coba Formulir Digital RCA Imunisasi Dasar dan Lanjutan Pada Pengguna}

Berdasarkan hasil uji coba yang telah dilakukan oleh pengguna yang akan menggunakan formulir digital RCA imunisasi, diperoleh bahwa pengguna yang terlibat pada tahap uji coba telah mampu melakukan entry data menggunakan formulir digital berbasis Epicollect5 Data Collection. Fitur required yang diterapkan pada setiap pertanyaan telah mampu memberikan notifikasi adanya pertanyaan yang belum terjawab. Fitur jumps yang ditambahkan pada formulir digital telah dapat berfungsi dengan baik. Adanya fitur jumps telah mampu mencegah terjadinya kesalahan pengisian kuesioner karena pertanyaan-pertanyaan yang tidak perlu ditanyakan dapat dilompati dan tidak ditampilkan pada formulir digital. Fitur jumps telah mampu menampilkan pertanyaan-pertanyaan sesuai dengan kondisi-kondisi jawaban yang diberikan responden. Berdasarkan hasil pengamatan selama proses uji coba, peneliti menemukan masih ada pengguna yang mengalami kendala dalam proses entry data, yaitu pada saat mengambil koordinat GPS dan memasukan data tanggal ke dalam formulir digital.

\section{Evaluasi Penerimaan Pengguna Terhadap Formulir Digital RCA Imunisasi Dasar dan Lanjutan}

Evaluasi terhadap penerimaan pengguna dinilai berdasarkan tiga aspek yang diadopsi dari model Unified Theory of Acceptance and Use of Technology (UTAUT), yaitu ekspektasi kinerja, ekspektasi usaha, dan minat memanfaatkan formulir digital. Penilaian dilakukan menggunakan sebuah kuesioner dengan mengadopsi item-item pertanyaan pada model UTAUT dengan empat kategori jawaban, yaitu sangat tidak setuju (STS), tidak setuju (TS), setuju (S), dan sangat setuju (SS).

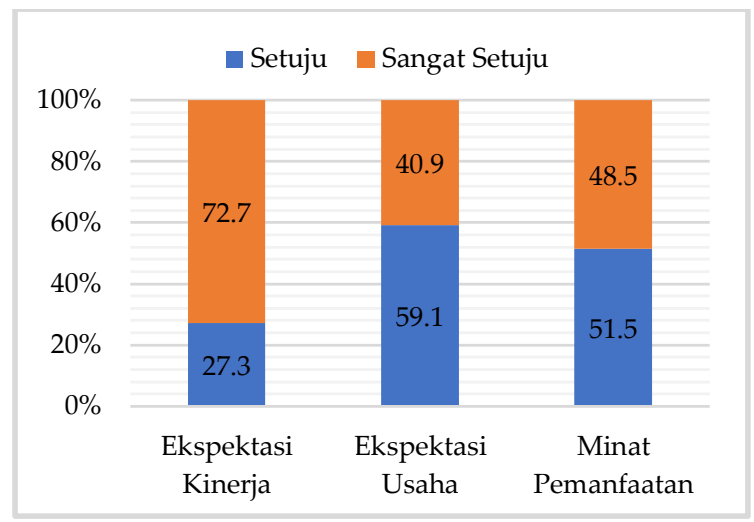

Gambar 8. Hasil Analisis Penerimaan Pengguna Menggunakan Model UTAUT.

Berdasarkan hasil analisis data, didapatkan bahwa seluruh pengguna yang terlibat dalam tahap uji coba memberikan tanggapan atau jawaban yang positif terhadap penggunaan formulir digital RCA imunisasi dasar dan lanjutan. Berdasarkan aspek ekspektasi kinerja, sebanyak 27,3\% pernyataan pengguna menyatakan setuju dan $72,7 \%$ menyatakan sangat setuju bahwa formulir digital yang dikembangkan dapat membantu dalam meningkatkan kinerja dalam bekerja. Berdasarkan aspek ekspektasi usaha, sebanyak 69,1\% pernyataan pengguna menyatakan setuju dan 40,9\% menyatakan sangat setuju bahwa formulir digital yang dikembangkan mudah untuk digunakan sehingga dapat mengurangi upaya, tenaga dan waktu dalam melakukan pekerjaan. Lalu berdasarkan aspek minat pemanfaatan diperoleh hasil sebanyak $51,5 \%$ pernyataan pengguna meyatakan setuju dan 48,5\% menyatakan sangat setuju bahwa mereka 
berkeinginan atau berminat untuk menggunakan formulir digital yang dikembangkan dalam kegiatan RCA imunisasi yang akan datang.

Terdapat beberapa masukan untuk perbaikan formulir digital yang diberikan oleh pengguna yang melakukan uji coba. Pertama, yaitu penambahan pilihan jawaban pada nama puskesmas lokasi RCA imunisasi. Kedua, cara pengisian tanggal imunisasi yang dilakukan dengan memilih tanggal pada tampilan kalender sebaiknya diganti dengan mengetik secara manual agar mempermudah proses pengisian data. Ketiga, pilihan jawaban "petugas kesehatan" pada pertanyaan sumber informasi untuk memperoleh imunisasi perlu ditambahkan keterangan mengenai petugas kesehatan yang dimaksud, yaitu dokter, bidan, dan perawat. Masukanmasukan yang diberikan sifatnya hanya perbaikan pada item pertanyaan yang telah ada tanpa perlu dilakukan penghapusan atau penambahan item pertanyaan.

\section{DISKUSI}

Formulir digital RCA imunisasi dasar dan lanjutan merupakan sebuah instrumen pengumpulan data yang dapat digunakan pada ponsel pintar dengan menggunakan basis aplikasi Epicollect5 Data Collection yang dikembangkan oleh peneliti untuk digunakan dalam kegiatan Rapid Convenience Assessment (RCA) imunisasi dasar dan lanjutan di Provinsi Bali.

Terdapat beberapa keuntungan yang diberikan dari penggunaan sistem digital dalam proses pengumpulan data pada kegiatan survei. Pengumpulan data dengan sistem digital berbasis ponsel pintar memiliki kemungkinan mengalami kesalahan entry data yang lebih kecil dibandingkan dengan pengumpulan data menggunakan kuesioner berbasis kertas (Zhang et al., 2012). Penggunaan sistem digital juga mampu meningkatkan kelengkapan dan akurasi data yang dihasilkan (Garcia-Palacios et al., 2014). Pada pengumpulan data untuk kegiatan survei, sistem digital dapat meningkatkan kapasitas dan kecepatan pengumpulan data, serta meminimalisisr biaya yang diperlukan dalam pelaksanaan survei (Belasario et al., 2015). Berdasarkan ulasan tersebut, maka penggunaan sistem digital berbasis ponsel pintar dapat digunakan sebagai instrumen pengumpulan data yang baru untuk mengatasi permasalahan yang dialami dalam kegiatan RCA imunisasi dasar dan lanjutan.

Seluruh proses pengumpulan data dengan formulir digital dilakukan di dalam aplikasi Epicollect5 Data Collection. Sebelum melakukan pengumpulan data, hal pertama yang harus dilakukan yaitu menginstal aplikasi Epicollect5 Data Collection pada ponsel pintar, lalu mengunduh formulir digital RCA imunisasi pada aplikasi tersebut. Formulir digital yang telah diunduh sudah dapat digunakan untuk wawancara dan mengumpulkan data dari responden. Setelah selesai melakukan pengumpulan data, formulir-formulir yang di dalamnya terdapat data hasil wawancara akan dikirim ke server Epicollect. Data yang telah masuk ke server Epicollect ditampilkan dalam bentuk tabel. Seluruh data yang telah masuk ke server dapat diunduh dalam format file .csv yang selanjutnya dapat dikonversi menjadi dokumen microsoft excel dengan format .xls atau .xlsx. Output data yang dapat diunduh dalam format microsoft 
excel menyebabkan petugas imunisasi tidak perlu melakukan pengumpulan data dua kali, karena pencatatan data hanya perlu dilakukan pada saat mengisi formulir digital dan tidak ada proses memasukan data secara manual ke dalam dokumen microsoft excel. Secara keseluruhan, penggunaan formulir digital dapat meningkatkan efisiensi waktu, karena tidak adanya proses memasukan data ke dalam microsoft excel secara manual, serta data yang diunduh dengan format dokumen excel dapat langsung diproses menuju tahap analisis sehingga akan lebih cepat untuk memperoleh hasil analisis data. Selain ditampilkan dalam bentuk tabel, data pada server Epicollect juga dapat ditampilkan dalam bentuk peta titik atau dot maps yang menggambarkan sebaran rumah responden RCA imunisasi. Website Epicollect juga menyediakan fitur analisis sederhana berupa distribusi frekuensi dari pertanyaan atau variabel yang ditampilkan dalam bentuk diagram lingkaran.

Formulir digital RCA imunisasi dioperasikan menggunakan aplikasi Epicollect5 Data Collection, sehingga pengguna diharapkan memiliki pemahaman mengenai bagaimana cara pengoperasian aplikasi pada ponsel pintar. Beberapa hal lain pada ponsel pintar yang perlu dipahami oleh pengguna yaitu penggunaan fitur GPS untuk mengambil koordinat lokasi, karena terdapat pertanyaan untuk mengambil koordinast lokasi rumah responden dalam formulir digital. Selain itu, pengguna juga diharapkan mampu menggunakan internet karena beberapa proses selama penggunaan formulir digital membutuhkan koneksi internet yang terhubung pada ponsel.
Koneksi internet diperlukan ketika mengunduh formulir digital untuk dipasang pada aplikasi Epicollect5 Data Collection, dan ketika mengirimkan data yang telah terkumpul pada formulir digital ke server Epicollect. Proses pengumpulan data dengan menggunakan formulir digital tidak membutuhkan koneksi internet, sehingga pengumpulan data di wilayah dengan koneksi internet yang buruk tetap dapat dilaksanakan. Apabila pengumpulan data dilakukan di daerah yang internetnya tidak memadai, maka pengiriman data ke server dapat dilakukan setelah meninggalkan daerah tersebut dan ketika ponsel sudah mendapat koneksi internet. Oleh sebab itu, pengiriman data tidak akan terhambat meskipun pengumpulan data dilakukan di wilayah dengan internet yang kurang mendukung.

Formulir digital RCA imunisasi dasar dan lanjutan berpotensi untuk dapat digunakan pada daerah lain di luar Provinsi Bali oleh dinas kesehatan terkait. Sebagian besar pegawai di lingkungan dinas kesehatan seluruh Indonesia sekiranya telah cakap mengoperasikan ponsel pintar (smartphone). Berdasarkan hasil survei yang dilakukan sebuah perusahaan teknologi bekerjasama dengan Dewan Pengurus Korpri Nasional (DPKN), dari seluruh responden yang merupakan Aparatur Sipil Negara (ASN) yang tersebar di seluruh provinsi, didapatkan hasil bahwa 72,94\% responden telah menggunakan smartphone, serta $71,13 \%$ responden menyatakan aktif mengakses internet setiap harinya (Redaksi Liputan6, 2016). Kondisi tersebut memungkinkan pegawai dinas kesehatan di daerah lain untuk mampu beradaptasi dan menggunakan formulir digital RCA 
imunisasi. Namun, apabila suatu dinas kesehatan ingin melaksanakan kegiatan RCA imunisasi dan menggunakan formulir digital, pada dinas kesehatan tersebut harus ada petugas yang memiliki kemampuan baik dalam mengoperasikan website yang nantinya petugas tersebut akan menjadi pengelola wesbite Epicollect. Hal tersebut dikarenakan proses perancangan dan penyusunan pertanyaan formulir digital dilakukan di dalam website epicollect, serta data dari responden kegiatan RCA imunisasi juga dikumpulkan pada server di dalam website.

Berdasarkan hasil evaluasi penerimaan dari subyek penelitian terhadap formulir digital RCA imunisasi, diperoleh hasil bahwa berdasarkan aspek ekspektasi kinerja, sebanyak 27,3\% pernyataan responden menyatakan setuju dan $72,7 \%$ menyatakan sangat setuju bahwa menggunakan formulir digital mampu membantu dalam meningkatkan kinerja dalam bekerja. Hal tersebut menunjukan bahwa menggunakan formulir digital mampu memberikan manfaat bagi pengguna dan membantu dalam menyelesaikan pekerjaan lebih cepat. Output data dari formulir digital yang dapat langsung diunduh dalam format dokumen microsoft excel mampu membantu petugas imunisasi karena petugas tidak perlu melakukan entry data atau memasukan data secara manual ke dalam dokumen microsoft excel. Hal tersebut mampu meningkatkan efisiensi waktu petugas imunisasi dalam menyelesaikan pekerjaan, serta mempercepat proses data untuk dilanjutkan menuju tahap analisis.

Berdasarkan aspek ekspektasi usaha atau tingkat kemudahan penggunaan formulir digital, sebanyak $59,1 \%$ dari seluruh tanggapan yang diberikan responden menyatakan setuju dan 40,9\% lainnya menyatakan sangat setuju bahwa formulir digital RCA imunisasi mudah digunakan. Seluruh petugas yang terlibat dalam uji coba menyatakan bahwa mereka aktif dalam menggunakan ponsel pintar dab internet. Hal tersebut menyebabkan petugas lebih mudah beradaptasi dengan aplikasi Epicollect5 Data Collection yang digunakan sebagai formulir digital. Namun, meskipun seluruh pengguna yang terlibat dalam uji coba memberikan tanggapan positif terkait kemudahan penggunaan formulir digital, peneliti masih menemukan beberapa pengguna yang memiliki kendala dalam proses entry data pada saat uji coba. Beberapa pengguna masih belum lancar dalam menggunakan fitur koordinat lokasi GPS, terutama dalam penentuan akurasi. Angka akurasi yang didapatkan harus sekecil mungkin agar koordinat yang diambil tepat dengan lokasi rumah responden. Namun, tingkat akurasi GPS sangat dipengaruhi oleh posisi ponsel pada saat mengambil koordinat. GPS tidak dapat berfungsi dengan baik apabila digunakan di dalam ruangan atau gedung, sehingga menyebabkan akurasi yang rendah. GPS akan menghasilkan akurasi yang baik apabila digunakan diluar ruangan (Haniah \& Putra, 2015). Selain itu, terdapat pengguna yang sedikit terkendala dalam memasukan tanggal imunisasi ke dalam formulir digital. Tanggal imunisasi dimasukan dengan cara memilih tanggal pada tampilan kalender yang muncul pada formulir digital. Hal tersebut mengharuskan pengguna memasukan tanggal dengan cara menggeser dan 
memilih halaman kalender hingga menemukan tanggal yang diinginkan.

Berdasarkan penilaian terhadap aspek minat memanfaatkan formulir digital, sebanyak $51,5 \%$ dari pernyataan responden menyatakan setuju dan $48,5 \%$ menyatakan sangat setuju bahwa mereka berminat dan berkeinginan menggunakan formulir digital yang dikembangkan untuk kegitaan RCA imunisasi yang kedepannya akan dilaksanakan. Hal tersebut sejalan dengan penilaian yang diberikan oleh responden pada aspek ekspektasi kinerja dan ekspektasi usaha yang memberikan tanggapan positif bahwa formulir digital RCA imunisasi mampu meningkatkan kinerja dan mudah untuk digunakan.

Berdasarkan hasil kuesioner penerimaan pengguna, terdapat beberapa masukan untuk perbaikan formulir digital yang diberikan oleh pengguna. Masukan yang diberikan yaitu menambahkan pilihan jawaban nama puskesmas pada pertanyaan puskesmas lokasi RCA, mengganti metode pengisian tanggal imunisasi, dan menambahkan keterangan petugas kesehatan yang dimaksud pada pertanyaan sumber informasi tentang imunisasi. Perbaikan yang peneliti lakukan telah dikonsultasikan terlebih dahulu dengan pihak Dinas Kesehatan Provinsi Bali. Perbaikan yang dilakukan oleh peneliti yaitu penambahan pilihan jawaban pada pertanyaan puskesmas lokasi pelaksanaan RCA imunisasi. Berdasarkan uji coba yang telah dilakukan, petugas imunisasi memasukan nama puskesmas dengan format penulisan yang berbeda-beda, yaitu dalam hal penulisan nomor dan singkatan nama puskesmas. Adanya pilihan nama puskesmas yang muncul pada pertanyaan tersebut akan memudahkan petugas karena tidak perlu mengetik nama puskesmas. Selain itu, dengan adanya pilihan tersebut, data nama puskesmas yang masuk ke server Epicollect akan memiliki format penulisan yang seragam, sehingga akan mempermudah dalam pengelompokan data dan proses analisis data.

Peneliti tidak melakukan perbaikan mengenai metode pengisian tanggal memperoleh imunisasi yang direkomendasikan untuk diketik secara manual. Pengisian data mengenai tanggal imunisasi dengan cara memilih tanggal pada tampilan kalender yang muncul dalam formulir digital merupakan cara yang lebih baik dibandingkan dengan mengetik secara manual. Cara tersebut dikatakan lebih baik karena data tanggal yang tercatat dalam formulir digital akan memiliki format yang sama untuk seluruh data, sehingga akan memudahkan dalam tahap analisis data karena seluruh data tanggal telah memiliki format yang sama. Apabila tanggal diketik secara manual akan memungkinkan terjadinya format penulisan yang tidak seragam, sehingga akan memerlukan waktu yang lebih untuk melakukan cleaning atau editing terhadap data tersebut sebelum data dianalisis. Peneliti juga tidak melakukan perbaikan untuk pilihan jawaban "petugas kesehatan" pada pertanyaan sumber informasi yang diakses untuk mengetahui informasi imunisasi. Berdasarkan hasil uji coba, terdapat pengguna yang menyarankan pilihan jawaban "petugas kesehatan" diganti menjadi "petugas kesehatan (bidan, dokter, perawat)". Pilihan jawaban yang disarankan memberikan definisi yang kurang luas mengenai petugas kesehatan 
yang dimaksud, karena terdapat petugas kesehatan lainnya yang mungkin untuk memberikan informasi imunisasi kepada masyarakat selain dokter, bidan, dan perawat. Selain itu, sebagian besar pengguna yang terlibat selama proses uji coba tidak mempermasalahkan pilihan jawaban tersebut yang hanya tertulis “petugas kesehatan". Maka dari itu, peneliti tidak melakukan perbaikan terhadap pertanyaan tersebut.

\section{SIMPULAN}

Formulir Digital RCA imunisasi dasar dan lanjutan dibuat dalam aplikasi Epicollect5 Data Collection yang terdiri dari lima bagian yaitu form identitas formulir, lokasi pelaksanaan RCA imunisasi, identitas responden, imunisasi dasar, dan imunisasi lanjut. Hasil evaluasi penerimaan pengguna menunjukan bahwa seluruh peserta uji coba memberikan tanggapan yang positif (setuju dan sangat setuju) terhadap penggunaan formulir digital RCA imunisasi berdasarkan aspek ekspektasi kinerja, ekspektasi usaha, dan minat memanfaatkan formulir digital.

\section{KELEMAHAN PENELITIAN}

Penelitian ini masih memiliki beberapa kelemahan. Pertama, pelaksanaan uji coba formulir digital belum dapat dilakukan di lapangan dengan wawancara langsung kepada orang tua bayi karena adanya pandemi covid-19. Kedua, penelitian ini menilai penerimaan pengguna tanpa memperhitungkan pengaruh variabel lain yang dapat mempengaruhi penerimaan pengguna, sehingga diperlukan penelitian lebih lanjut untuk menilai penerimaan dengan memperhatikan variabel yang mungkin berpengaruh. Ketiga, Penelitian ini hanya mengembangkan instrumen pengumpulan data dan belum mencakup pengembangan register data yang mampu menampilkan hasil analisis yang diperlukan secara otomatis.

\section{SARAN}

Pihak terkait diharapkan dapat melakukan penyempurnaan mengenai penelitian ini dengan mengadakan uji coba yang lebih luas pada jumlah peserta dan waktu yang lebih lama, serta dilakukan dengan turun langsung ke lapangan menggunakan orang tua bayi sebagai responden dalam uji coba. Sehingga akan dapat mengetahui masukan, saran, maupun permasalahan berkaitan dengan aspek informasi dan sistem dari formulir digital. Diharapkan pula bagi peneliti lain untuk melakukan pengembangan register data yang dapat menghasilkan luaran analisis secara otomatis sebagai salah satu bentuk penyempurnaan terhadap instrumen formulir digital yang sudah dikembangkan pada penelitian ini.

\section{DAFTAR PUSTAKA}

Aanensen, D. M., Huntley, D. M., Feil, E. J., Al-Own, F., \& Spratt, B. G. (2009). EpiCollect: Linking Smartphones to Web Applications for Epidemiology, Ecology and Community Data Collection. PLOS ONE, 4(9). https://doi.org/10.1371/journal.pone.00 06968

Belasario, M., J, J., K, H., J, O., CP, M., \& J, C. (2015). Comparison of self administered survey questionnaire responses collected using mobile apps versus other methods. Cochrane Database of Systematic Reviews. 
https://doi.org/10.1002/14651858.MR00 0042

BPS Provinsi Bali. (2020). Persentase Penduduk Usia 5 Tahun ke Atas yang Mengakses Teknologi Informasi dan Komunikasi (TIK) dalam 3 Bulan Terakhir Menurut Kabupaten/Kota, 2019. Retrieved June 29, 2020, from https://bali.bps.go.id/statictable/2018/0 4/13/95/persentase-penduduk-usia-5tahun-ke-atas-yang-mengaksesteknologi-informasi-dan-komunikasitik-dalam-3-bulan-terakhir-menurutkabupaten-kota-2018.html

Dinas Kesehatan Provinsi Bali (B). (2019). Proposal Pelaksanaan Rapid Convenience Assessment (RCA) Pelaksanaan Imunisasi Dasar dan Lanjutan di Provinsi Bali Tahun 2019.

Garcia-Palacios, A., Herrero, R., Belmonte, M. A., Castilla, D., Guixeres, J., Molinari, G., ... Botella, C. (2014). Ecological momentary assessment for chronic pain in fibromyalgia using a smartphone: A randomized crossover study. European Journal of Pain, 18(6), 862-872. https://doi.org/10.1002/j.15322149.2013.00425.x

Haniah, \& Putra, A. E. (2015). Purwarupa Portable Global Positioning System. IJEIS (Indonesian Journal of Electronics and Instrumentation Systems), 3(1), 105. https://doi.org/10.22146/ijeis.3876

Madder, M., Walker, J. G., Van Rooyen, J., Knobel, D., Vandamme, E., Berkvens, D., ... De Clercq, E. M. (2012). ESurveillance in Animal Health: Use and evaluation of mobile tools. Parasitology, 139(14), 1831-1842. https://doi.org/10.1017/S003118201200 0571
Rasyid, M. Z., Notobroto, H. B., \& Hargono, A. (2016). Pengembangan Basis Data Imunisasi Dasar Lengkap Dan Booster Batita ( Studi Kasus Di Puskesmas Blega Kabupaten Bangkalan ) Development Database Basic Complete Immunization and Booster Toddler ( Case Study in Blega Health Center in Bangkalan Regency ). Jurnal Wiyata, 3(2), 187-198.

Redaksi Liputan6. (2016). Survei Buktikan PNS Sudah Melek Teknologi informasi - Lifestyle Liputan6.com. Retrieved June 29, 2020, from https://www.liputan6.com/lifestyle/re ad/2647362/survei-buktikan-pnssudah-melek-teknologi-informasi

Zhang, S., Wu, Q., Van Velthoven, Q. W. M. H. M. M. T., Chen, L., Car, J., Rudan, I., ... Scherpbier, R. W. (2012). Smartphone versus pen-and-paper data collection of infant feeding practices in rural China. Journal of Medical Internet Research, 14(5). https://doi.org/10.2196/jmir.2183 